NBER WORKING PAPER SERIES

POLITICAL BUDGET CYCLES:

EVIDENCE FROM ITALIAN CITIES

\author{
Alberto Alesina \\ Matteo Paradisi \\ Working Paper 20570 \\ http://www.nber.org/papers/w20570
NATIONAL BUREAU OF ECONOMIC RESEARCH
1050 Massachusetts Avenue
Cambridge, MA 02138
October 2014

We thank Ugo Troiano, Paolo Pinotti, the IFEL Foundation and Stefano Gagliarducci for generous help with the data. Massimo Bordignon, Raj Chetty, Anastasia Driva, Nicola Fontana and Tommaso Nannicini offered useful comments. We also thank participants in the seminars at Washington University St Louis and Leicester University. Giorgio Saponaro and Giacomo Lanzani provided excellent research assistantship. The views expressed herein are those of the authors and do not necessarily reflect the views of the National Bureau of Economic Research.

NBER working papers are circulated for discussion and comment purposes. They have not been peerreviewed or been subject to the review by the NBER Board of Directors that accompanies official NBER publications.

(C) 2014 by Alberto Alesina and Matteo Paradisi. All rights reserved. Short sections of text, not to exceed two paragraphs, may be quoted without explicit permission provided that full credit, including $(\mathcal{C}$ notice, is given to the source. 
Political Budget Cycles: Evidence from Italian Cities

Alberto Alesina and Matteo Paradisi

NBER Working Paper No. 20570

October 2014, Revised June 2013

JEL No. H0

\begin{abstract}
$\underline{\text { ABSTRACT }}$
The introduction of a new real estate taxes in Italy in 2011 generated a natural experiment, which is useful to test political budget cycles, i.e. the strategic choice of fiscal variables in relation to elections. We do find substantial evidence of political budget cycles, with municipalities choosing lower tax rates when close to elections. We observe this budget cycle only for smaller municipalities where the tax was more likely to be the single most important issue for the local government. Cities close to elections with large deficits did not set lower rates before elections, probably because they felt the binding constraints of budget rules.
\end{abstract}

\author{
Alberto Alesina \\ Department of Economics \\ Harvard University \\ Littauer Center 210 \\ Cambridge, MA 02138 \\ and IGIER \\ and also NBER \\ aalesina@harvard.edu \\ Matteo Paradisi \\ Department of Economics \\ Harvard University \\ Littauer 108 \\ Cambridge, MA 02138 \\ mparadisi@g.harvard.edu
}




\title{
Political Budget Cycles: Evidence From Italian Cities*
}

\author{
Alberto Alesina ${ }^{\dagger}$ Matteo Paradisi
}

First Draft: July, 2014

Revised: June, 2015

\begin{abstract}
The introduction of a new real estate taxes in Italy in 2011 generated a natural experiment, which is useful to test political budget cycles, i.e. the strategic choice of fiscal variables in relation to elections. We do find substantial evidence of political budget cycles, with municipalities choosing lower tax rates when close to elections. We observe this budget cycle only for smaller municipalities where the tax was more likely to be the single most important issue for the local government. Cities close to elections with large deficits did not set lower rates before elections, probably because they felt the binding constraints of budget rules.
\end{abstract}

JEL Codes: E62, H3, H7.

\section{Introduction}

Do governments strategically manipulate fiscal policy tools in order to win elections, for instance reducing taxes and/or increasing spending close to elections? The empirical evidence is far from a clear cut. Tufte (1978) answered "yes" for a handful of US elections. For other

${ }^{*}$ We thank Ugo Troiano, Paolo Pinotti, the IFEL Foundation and Stefano Gagliarducci for generous help with the data. Massimo Bordignon, Raj Chetty, Anastasia Driva, Nicola Fontana and Tommaso Nannicini offered useful comments. We also thank participants in the seminars at Washington University St Louis and Leicester University. Giorgio Saponaro and Giacomo Lanzani provided excellent research assistantship.

${ }^{\dagger}$ Harvard University and Igier (aalesina@harvard.edu).

${ }^{\ddagger}$ Harvard University (mparadisi@g.harvard.edu). 
countries work by Persson and Tabellini (2002) and Brender and Drazen (2005) show that political budget cycles occur only in certain countries under special circumstances.

In this paper we present evidence on Italian cities, where a recent policy development allows for a well designed test. In late 2011 the national government introduced a new real estate tax allowing cities some flexibility on the rate. The policy was very salient, discussed at length in the Parliament and in the press. In fact, given the large share of wealth held by Italians in real estate, it was a major policy issue and it represented the main independent source of revenues for local governments. Italian cities have staggered times of elections and this feature allowed us to test whether the tax rate chosen was affected by the distance from the next election. ${ }^{1}$

Our results show clear evidence of "political budget cycles", namely municipalities chose lower tax rates when close to elections. We estimate a deterioration of $6 \%$ in deficit per capita due to the cycle.

The evidence is stronger in smaller cities, where the real estate tax was probably the dominant policy issue. Also, the cycle is stronger in the South. A vast literature (Putnam et al (1993) and Guiso et al. (2013) amongst others) has pointed out how the level of trust, civicness, participation in social and political activities is lower in Southern Italy than in the rest of the country. Nannicini et al (2013) argue that lower social capital implies lesser control of politicians. Therefore, the latter may feel less constrained in pursuing strategic manipulation of policies; these results confirm the early intuition by Banfield (1958). The political budget cycle is however smaller in cities which had larger deficits. We believe this is because when deficit is high it becomes a central issue in elections and governments tend to adjust it.

The literature on political budget cycles is vast. The theoretical underpinning is due to Rogoff and Sibert (1988) and Rogoff (1990). They show how these cycles may persist even with rational voters if the latter are imperfectly informed about the complexities of the government budget and if they learn with a delay the full set of fiscal variables in play. As for the empirical evidence, at the national level the literature includes both papers on cross-country samples and papers focusing only on one country. In the first group Alesina et al. (1997) find evidence of cycles in the aggregate balance, but no evidence of cycles in single budget components for a sample of 13 OECD economies over the period 1960-1993. Shi and Svensson (2002) employs

\footnotetext{
${ }^{1}$ The reason of staggered dates is that notwithstanding all Italian cities voted for the first time in 1946 in many municipalities the process of renewal of the municipal councils did not follow the regular five-year cycle. The most common reasons were the fall of the government and political scandals that forced the governments of some municipalities to resign prematurely.
} 
a panel of 123 countries in the years 1975-1995 and shows some evidence of budget cycles in developing countries. Persson and Tabellini (2002) in a sample of 60 democracies over the period 1960-1998 find a revenue cycle only in presidential systems, but no political cycle on spending and transfers. Brender and Drazen (2005) find political budget cycles only in new democracies. $^{2}$ Several papers also look at national level cycles for specific countries. ${ }^{3}$

Our work is closer to another branch of literature that focuses on the subnational level. The study of local governments in the same country allows to hold constant a series of cultural and institutional characteristics that can potentially threaten the identification of causal effects in a cross-country analysis. Akhmedov and Zhuravskaya (2004) consider Russian provinces and show evidence of an increase of transfers to voters before elections. They exploit the orthogonality of election timing to implemented policies. However, as they point out, part of their sample moves elections away from the originally scheduled date creating concerns about the identification. We do not have this problem. Khemani (2000) show that electoral budget cycles affect the composition of local budgets. ${ }^{4}$ Evidence of local political budget cycles is also found by Reid (1998) and Kneebone and McKenzie (2001) for Canadian provinces, and by Drazen and Eslava (2003) for Colombia. ${ }^{5}$

Our work has some advantages. Unlike previous papers we focus on actual policy changes by looking at a specific tax rate, rather than changes in aggregate quantities (tax revenues or total spending). Obviously, previous papers try to control for some cycle-linked variables to isolate the discretionary change, but the identification is always debatable. ${ }^{6}$ We directly observe the discretionary tax rate.

\footnotetext{
${ }^{2}$ Other works on a cross-section of countries are Ames (1987) that shows the presence of budget cycles in 17 Latin American countries, Block (2002) finding evidence of political budget cycles in both monetary and fiscal policy in 44 Sub-Saharan countries and Schuknecht (1996) that focuses on 35 developing countries over the years between 1970-1992.

${ }^{3}$ Ben-Porath (1975) has evidence on budget cycles on the revenue side in Israel; Krueger and Turan (1993) in Turkey and Gonzales (1999) for Mexico. Keech and Pak (1989) find a cycle for veteran benefits in the United States and Alesina Cohen and Roubini (1992) show a cyclical behavior of transfers over GNP in the United States between 1961 and 1985 .

${ }^{4}$ For the reasons that threaten the identification in Akhmedov and Zhuravskaya (2004) his identification had to rely on instruments.

${ }^{5}$ Eslava (2005) confirms these findings underlining the change in the composition of public spending in local budgets, that is not followed by an increase in the total deficit.

${ }^{6}$ Another paper has already used the "natural experiment" of a property tax in Italy to investigate other political economy model. Bordignon and Turati (2014) show that after the introduction of a previous real estate tax in Italy in 1993, which allowed municipalities some degree of fiscal independence, the quality of politicians improved for rich municipalities.
} 
The present paper is organized as follows. Section 2 briefly describes the institutional setting. Section 3 describes our identification strategy, and Section 4 the data. Section 5 presents our results. The last section concludes.

\section{Institutional Background}

The IMU ("Imposta municipale unica", unique municipal tax) is a property tax introduced in Italy in late 2011 on all 8092 municipalities. It was very salient and followed an acrimonious debate in Parliament which had an immense coverage in the press. The tax was in fact passed as part of an emergency fiscal package that a newly appointed government designed to respond to an increasing pressure of financial markets on Italian sovereign debt yields. About $50 \%$ of the IMU tax revenue was transferred to the central government, while the remainder represented the main revenue source in municipal budgets (around 50\% of total revenues). Unlike the preexisting real estate tax (called ICI), the IMU applied also to the main residence in addition to all other properties. In Italy $61.9 \%$ of households own their residence ${ }^{7}$ and real estate investments represented in $201052 \%$ of total Italian households' assets with a ratio of housing wealth over income of 5.6 against 5.1 of France and United Kingdom and 2.1 of United States (Neri and Monteduro (2010) and Banca d'Italia (2011)). The "tax free" status of the main residence was considered by many as an untouchable feature of the tax code. Thus, the political debate over this tax was very intense.

The national government set a default rate for each category of houses (main residence, additional ones and rural property), with a range of discretion for the municipalities. The default rate for main residences was $0.4 \%$ with a window between $0.2 \%$ and $0.6 \%$; rural buildings had a default tax rate of $0.2 \%$ that could be decreased to zero; additional residences had a default rate of $0.76 \%$ which could be moved in the interval $0.46 \%-1.06 \%$. The tax base on which rates were applied was computed using a formula employing the book value of the property. Each municipality had to define tax rates for 2012 through a municipal council deliberation. If a municipality did not deliberate, the default rates applied. The central government imposed a deadline for the deliberation that was first scheduled for September 30th of 2012 and then moved to October 31st; the deadline for tax payment was set on the 17 th of December. ${ }^{8}$ The to-

\footnotetext{
${ }^{7}$ Computations on OECD Housing Market Questionnaire.

8 The process of deliberation was characterized by a back and forth of information. This led to multiple deliberations in many municipalities. However, by the 31st of October all rates for the year 2012 were defined.
} 
tal tax revenue raised with IMU in 2012 was 23.7 billion euros, paid by 25.8 million of taxpayers.

\section{Identification Strategy}

We plan to estimate the causal effect of upcoming elections on an outcome that we call $Y$, the tax rate. Our treatment in the baseline specification is denoted by Elec and takes value 1 in cities where elections are held. We denote with $Y_{i}$ and $E l e c_{i}$ respectively the outcome and treatment of a generic city $i$. The potential outcomes for each $i$ in the control and treatment group are $Y_{i, 0}$ and $Y_{i, 1}$ respectively.

We are interested in the estimation of the average treatment effect, which is $E\left(Y_{i, 1}-Y_{i, 0}\right)$. In order to identify the latter, we need orthogonality between treatment and potential outcomes. This is guaranteed by the institutional design of IMU. Indeed, we exploit the fact that the central government imposes the tax on all cities and sets a deadline for the deliberation of tax rates within the year, avoiding any strategic behavior of municipal governments in choosing the year of the introduction of taxes.

Figure 1 clarifies the timeline of the reform. In light of this, being in an electoral year is as good as randomly assigned. On the contrary, suppose there were not a deadline, the occurrence of deliberations could be dependent on the presence of elections in the year and we would have selection into sample. We implicitly assume here that the distribution of election terms across municipalities did not influence the introduction of the tax. This assumption would be violated, for instance, in case municipalities could affect the decision of the central government by making some political pressure through parties that operate in the Parliament. However, first there was international pressure to reduce budget deficit at the moment of the reform, it was indeed an "emergency technical government" that introduced the new tax; second the government was supported by a coalition ranging from center left to center right parties. For these reasons we feel confident that we can exclude political pressure from specific municipalities.

Thus, we argue the following:

Assumption 1: The imposition of a deadline for the deliberation, set by the end of 2012, guarantees that $Y_{i, 0}, Y_{i, 1} \perp$ Elec $_{i}$.

We must also assume that the treatment of each city i does not affect the potential outcomes of other cities. In other words, there must be no externalities. Thus, we posit Stable Unit Treatment Value Assumption (SUTVA). Write the potential outcome of each city as a function 
of the vector of treatments Elec, we have $Y_{i}(E l e c)$ for every municipality. The SUTVA implies that:

Assumption 2: $Y_{i}\left(\right.$ Elec $_{i}$, Elec $\left._{-i}\right)=Y_{i}\left(\right.$ Elec $\left._{i}\right)$ for every $i$, where $Y_{i}\left(\right.$ Elec $\left._{i}\right)$ is either $Y_{i, 1}$ or $Y_{i, 0}$.

where $E l e c_{-i}$ is the vector of treatments for all the observations except $i$. The assumption would not be satisfied if there were strategic interactions between municipalities. We could imagine that municipalities which are geographically close to each other set tax rates depending on the choice of their neighbors in a Bertrand type competition. If this were the case, elections in one municipality might reduce tax rates also in neighboring cities. Thus, imposing the SUTVA we would estimate a lower bound on the political budget cycle effect, since the competition would mitigate the gap between treatments and controls.

Under Assumptions 1 and 2 we can identify the effect of interest by running the following model:

$$
Y_{p, i}=\beta E l e c_{p, i}+\gamma X_{p, i}+\lambda_{p}+\varepsilon_{p, i}
$$

where Elec gets value 1 when elections are held, $p$ denotes the province of each municipality and $\lambda_{p}$ are provincial fixed-effects. There are 109 provinces in Italy, they can be thought as large counties in the US. We impose these fixed-effects to rule out any confounder that is constant at the provincial level guaranteeing that the result is not driven by various aspects that might not be balanced between different geographical areas. $X$ is a vector of covariates that include the constant.

We perform two tests using 2012 deliberation data. Our natural experiment generates a complication for the estimation of political budget cycles in 2012 using the strategy defined above. In fact, the deadline imposed by the national government for deliberations was the 31st of October, after elections were held on the 6th and 7th of May. The consequence is that we cannot take election in 2012 as our treatment variable. Indeed, municipalities were free to deliberate in any moment before the deadline and could have easily moved the deliberation after elections. Thus, if we used as a treatment the fact of having deliberated before elections, being an electoral municipality in 2012, we would introduce endogeneity in the model: municipalities would be selected into treatment.

Thus we take the characteristic of having elections scheduled for 2013 as our treatment and we assess whether this has an effect on tax rates set in 2012. In this case municipalities are not selected into treatment since being in an electoral year is orthogonal to every unobservable 
factor. Thus, Assumption 1 and 2 are satisfied and we can achieve identification. We construct the dummy for elections in 2013 by taking into account the information set of local governments in 2012 classifying as municipalities electing in 2013 those that were expected to have the end of the term in 2013 at the beginning of 2012. Thus, we exclude the threat to identification coming from cases in which municipalities could have anticipated elections in 2013 because of a political crisis linked to the deliberated tax rates. In that case in fact, the treatment would not be orthogonal to potential outcomes. However, the municipalities that had elections scheduled after 2013, but anticipated them in 2013 are less than 20 out of a sample of more than 8000 municipalities. The latter, jointly with the reasons of anticipation (mostly death of the mayor or corruption scandals), suggests that this is not a concern.

The second experiment is to assess whether the number of years lasting to the following elections can have an effect on the deliberated tax rates. In order to do that we restrict our sample excluding municipalities electing in $2012 .{ }^{9}$ Once we do that, the number of years lasting to next elections in each municipality is as good as randomly allocated. We thus estimate the following:

$$
Y_{p, i}=\beta N T E_{p, i}+\gamma X_{p, i}+\lambda_{p}+\varepsilon_{p, i}
$$

where $N T E$ counts the number of years lasting to next elections for municipalities that do not elect in 2012.

\section{Data}

We collected the dates (day, month, year) in which each municipality council deliberated the specific tax rates. ${ }^{10}$ These data for both 2012 and 2013 have been provided by Istituto per la Finanza e l'Economia Locale (IFEL) Foundation and the Italian Ministry of Economy and Finance.

Since the deliberation of a tax rate was not mandatory, not all the municipalities decided to formally fix these parameters: this is why not all the municipalities have at least one deliberation in 2012, when the tax has been introduced. ${ }^{11}$ These cities apply the standard rates $(0.4 \%$,

\footnotetext{
${ }^{9}$ The reason why we exclude them is that if we included them, we would generate endogeneity. We would in fact treat those deliberating after elections as if they were at the beginning of the term and the municipalities deliberating before elections as if they were in the election year, letting the variable be endogenously determined.

${ }^{10}$ The law included also some tax credits that are excluded from our analysis since, as we show later, only a few municipalities moved the level of deductions away from the default rate.

${ }^{11}$ The number of municipalities that did not deliberate is very small.
} 
$0.76 \%$ and $0.2 \%^{12}$ ) as implicitly set by governments. ${ }^{13}$ In 2013 the rates would have applied if municipalities had not changed them through a new deliberation. The share of municipalities which deliberated in 2013 is lower (69\% against 97\%) than the previous year. ${ }^{14}$ In 2012 local governments preferred to use the additional residence tax rate rather than the main residence one as a source of additional funding. Indeed, a majority of them (65\%) maintained the Standard rate on the main residence, while only $43 \%$, did not change the rate on additional ones. The municipalities increasing the latter are almost as twice as those increasing the former.

There are three types of government in Italian cities: independent ones with local political groups not linked to national parties, center left and center right parties, the same coalitions as at the national level. Table 1 shows that governments of both left and right tend to set higher rates than Independent ones, but left wing tends to set higher rates than right. Furthermore, a higher share $(35 \%)$ of left wing local governments set a main house rate higher than the standard one with respect to right wing ones $(27.6 \%)$.

Recent economic and demographic data for each municipality, such as population, unemployment rate, number of active firms are from the 2011 Census of Population and Houses and the 2011 Census of Industry and Services are provided by ISTAT, the National Statistic Institute of Italy. Data about number of resident and non-resident held houses, altitude and municipal area extensions are taken from 2001 Census of Population and Houses and Statistical Atlas published by ISTAT as well. Other economic controls, such as per-capita taxable income, overall income and number of taxpayers come from 2013 IRPEF data held by the Italian Ministry of Economic and Finance. Deficit data for all municipalities and other measures included in 2011 balance sheets are from the database of the Italian Ministry of the Interior. ${ }^{15}$ Political data about the governing coalitions in municipalities come from the Italian Ministry of the Interior, as well. Descriptive statistics for all the variables employed are provided in Table 2.

In Table 3 we run some balance checks to assess the correlation between our covariates

\footnotetext{
${ }^{12}$ There is also a tax credit of 200 euros. The latter is uniquely applied to the main residence and is complemented with 50 euros of additional credit for every non economically-independent child with less than 26 years for a maximum of 400 euros.

${ }^{13}$ Few cities deliberated in order to choose the default rate set by the government.

14 Since municipalities were allowed to change their decision within 2012 and 2013, we can see in both years multiple deliberations in the same municipality. In these cases, the actual tax payed by citizens was computed using the rates and credits chosen with the last deliberation of the year.
}

15 Data regarding the whole Region of Trentino-Alto Adige, a region with a "special status" of autonomy are missing. 
and the treatments. The Table shows the differences in covariate values between treatment and control groups. In column 1 only 3 covariates are not balanced. However, the differences are very small: municipalities with elections have 0.002 more firms per capita, a $3 \%$ higher probability of having a right wing government and about 245 euros a year per capita more than non-electing ones. Even if differences are very small we could be concerned by the fact that electing municipalities might be more fiscally conservative. However, in our specifications we control for these characteristics and many other covariates and results stay significant. Differences seem to be more pronounced looking at elections in 2014, and they seem to go in the opposite direction suggesting that municipalities with elections may be less conservative. Indeed, they display smaller populations (4000 inhabitants less), smaller income (around $200 €$ a year less) and higher margin of majority in past elections (about $2 \%$ more). Again, when we control for unbalanced covariates results are robust.

\section{Elections and Tax Rates}

Table 4 reports the result of the estimation of model (1). Our regressions include provincial fixed-effects and clustered standard errors at the provincial level. The dependent variables are the tax rates set in the deliberations of 2012 and 2013 relative to the elections of 2013 and 2014 respectively. ${ }^{16}$ In column 1 we show the effect of having elections in 2013 on the main residence rate estimated without including any additional control. The coefficient is significantly estimated and negative, suggesting that municipalities with elections in 2013 set lower tax rates in 2012. The result does not change and its significance is robust to the inclusion of economic, demographic and geographic controls as displayed in column 2. In particular, we control for population in 2011, municipal area (and its square), altitude (and its square), the share of people having a high school or University degree, the number of firms per capita in 2011, the income per capita, deficit per capita, the number of main habitations per capita and the unemployment rate in 2011. ${ }^{17}$ Column 3 and 4 show the estimated coefficients for regressions having as dependent variable the tax rate on additional residence set in the last

16 The tax rates fixed in these last deliberations are those employed in the computation of the tax levy in December 2012 and December 2013.

\footnotetext{
${ }^{17}$ We also have results when controlling for additional covariates such as the political orientation of the municipality, the margin of majority in previous elections and the number of per capita non-profit organizations in the city.
} 
deliberation of 2012. The effect has the expected sign, but is not statistically significant.

In columns 5 and 6 of Table 4 we replicate the experiment with 2013 deliberation data. The IMU on the main residence was abolished in August 2013, after a harsh political and mediatic debate. As a consequence the tax on additional residences became even more salient and more important for local finances. We now observe a significant coefficient robust to the inclusion of controls.

We computed the average change in revenues induced by a shift of the main residence tax rate using average book values and population size. We estimate a loss of revenues for electing cities equivalent to $6 \%$ of deficit per capita in a single year.

All results in Table 4 are robust to the exclusion of one region at a time (there are 20 regions in Italy) and the inclusion of regional fixed-effects instead of provincial fixed-effects. Moreover, since we do not have data on deficit for some municipalities, the number of observations drops when we include controls. Therefore, as a further robustness check we run the regressions in column 1, 3 and 5 of Table 4 on the restricted sample for which we have all controls. Results do not change. ${ }^{18}$

We also run a nonparametric permutation test to assess the significance of $\beta$ in (1). We randomly reassign treatment (i.e. elections) on municipalities and run again model (1) for 10000 times. Denoting with $F(\hat{\beta})$ the cumulative distribution function for the estimates we obtain, the value of $F(\beta)$ (where $\beta$ is the estimate reported above) is analogous to the p-value for the hypothesis $\beta=0$. Figure 2 shows the plot of the cdf for the three specification presented in Tables 4. The values of $G(\beta)$ in the three cases are $0.12 \%, 8.03 \%$ and $0 \%$ confirming that the effect of elections is significant for the main residence rate and for the additional tax rate in 2014. The $8.03 \%$ also allows for the possibility that the effect of elections on additional tax rate in 2013 is significant.

We assess whether the tax rates are influenced by the distance from next administrative elections measured in number of years. Table 5 reports results from the estimation of the model in (2) and shows that the coefficient on the number of years lasting to next elections is positive and strongly significant for both tax rates. In particular, we estimate that being at the beginning of the term leads to a main residence tax rate 0.12 higher than the one that would be deliberated in the year before elections, and an additional residence tax rate 0.36 higher. Both results are robust to the inclusion of controls and to the same robustness checks described above. All these results are available upon request.

We then run our regression separately on North, Center and South of Italy. ${ }^{19}$ For what

\footnotetext{
${ }^{18}$ We also have results for regressions employing a larger number of controls. They are available upon request.

${ }^{19}$ The regions included in the North are: Friuli-Venezia Giulia, Liguria, Lombardia, Piemonte, Valle d'Aosta,
} 
concerns the tax rate on the main residence (see Table 6 Panel A), we find little evidence of cycles in the North, no evidence in the Center and a strong evidence of cycles in the South where the coefficient is negative, significant and higher than the one estimated for the entire sample. For tax rates on additional residence we find evidence of political budget cycles in the South and an increase of tax rates for cities with elections in the Center (see Table 6 Panel B). The result for the Center probably depends upon the political orientation (left) of the regions in this geographical area. In Panel C we find evidence of budget cycles in 2013 for all of the geographical areas with a stronger effect of elections for cities in the Center.

We expect that in small cities the IMU is more salient in the public debate given the limited range of issues that small city governments have to deal with. On the contrary, in bigger cities where the administration is more complex, we expect voters to base their electoral decision on many additional issues (e.g. the efficiency of public transports, the efficiency of bureaucracy or health services). If the incumbents anticipate this, in small cities we should observe a higher degree of political budget cycles. We therefore run our analysis constructing two samples using a threshold on the number of inhabitants. We report results in Table 7 using the threshold of 15000 inhabitants. $^{20}$ We find that political budget cycles on the main residence tax rate in 2012 are present only for small municipalities, while there is no such evidence in big cities. No significant effect is found for additional tax rates in 2012 for any size. Small cities shows significant effects of elections on tax rates again in 2014, where we find no evidence of the cycle on big municipalities.

As previously pointed out, the IMU is the main source of revenue for local governments. This implies that its importance in keeping a balanced fiscal stance depends on the level of deficit each municipality inherited from 2011. Table 8 reports the results for the estimation including an interacted term between the electoral dummy and the level of deficit per capita in 2011. In column 1 and 2 we find that when the dependent variable is the main residence rate set in 2012, the interaction gets a significant and positive coefficient, suggesting that among the cities with equal levels of deficit, those with elections in the subsequent year were more incline to set higher tax rates for the main residence. Controlling for deficit, the direct effect of the latter is already captured and does not influence the interaction coefficient. When deficit is high, it is more likely to become a salient issue in the electoral debate. Therefore, municipal governments with high deficits have a higher incentive to appear more fiscally prudent from

Trentino Alto Adige and Veneto. The Center includes: Emilia Romagna, Toscana, Umbria, Marche and Lazio. The South includes: Abruzzo, Molise, Campania, Calabria, Basilicata, Puglia, Sicilia and Sardegna.

${ }^{20}$ We employ here the threshold of 15000 inhabitants since it is the one used to distinguish between small and big cities by the electoral law. We also checked other thresholds to make sure that changes in electoral law are not confounding our estimates and results do not change much. 
voters' perspective. ${ }^{21}$ This effect can more than compensate the budget cycle observed in the coefficient of the electoral dummy. However, this occur for very high levels of deficit above 1000 euros per capita, which means more than three standard deviations above the mean. In columns 3 to 6 we find no evidence of an influence of deficit on budget cycles for the additional residences' tax rates.

The final step in our analysis looks at the heterogeneity introduced by different budget rules. The Italian government enforces a rather cumbersome European Stability and Growth Pact on the local governments by means of an Internal Stability Pact which every year designs new fiscal targets that become mandatory for local governments. In 2012 the Pact was enforced on all municipalities with more than 5000 inhabitants. We run our model above and below the threshold of 5000 for the data in 2012. Results are reported in Table 9 and show that the effects highlighted above on the deficit hold only for the sample of municipalities with less than 5000 inhabitants, while they disappear on the sample over 5000 inhabitants. $^{22}$ Our interpretation for these results is that in municipalities with more than 5000 inhabitants the voters are aware of the existence of deficit constraints and therefore evaluate a deficit reduction simply as the effect of the binding rule. On the other hand, when net borrowing is high, voters in smaller municipalities that are not subject to the Pact may reward the government after a deficit reduction regarding the latter as a sign of the government effort towards a sustainable fiscal stance. As a consequence, anticipating the voters behavior the governors could decide to increase taxes when the level of deficit is high, striving to get electoral support.

\section{Conclusion}

The introduction in 2011 of a new real estate tax in Italy provides an excellent natural experiment to test for strategic manipulations of fiscal instruments in anticipation of elections. Two features of this experiment are especially useful for identification: city governments had some discretion in the choice of the level of this tax rate on the main residence of a family and on additional residences, and the election date in cities is staggered. We find substantial

\footnotetext{
${ }^{21}$ The view that large deficits are seen as problematic by the voters and that deficit reducing governments are not systematically punished on election day is consistent with the evidence by Brender and Drazen (2008) and Alesina et al (2013).

${ }^{22}$ We confirm the absence of any evidence of political budget cycles for the additional residence tax in columns 5 to 8 .
} 
evidence of political budget cycles. The closer the local governments were to a new election, the lower the tax rate chosen; the results are robust to a host of controls and robustness tests. The cycle is larger in smaller cities where the real estate tax was clearly the main political issue on the table.

The size of the cycle is smaller for cities with elections in which deficits in 2011 were higher suggesting that budget concerns made it more difficult for cities to chose lower tax rates in that situation. This effect is stronger for cities with more discretion on their level of deficit.

We also find that the evidence on cycles is especially strong in the South of Italy. This is consistent with models which suggest that lower levels of civicness are associated with less controls of politicians who can then engage in strategic manipulations of policies.

\section{References}

[1] Akhmedov, A. and Zhuravskaya, E. (2004), "Opportunistic Political Cycles: Test in a Young Democracy Setting," Quarterly Journal of Economics 119, 1301-38.

[2] Alesina, A. D. Carloni, and G. Lecce (2013), "The Electoral Consequences of Large Fiscal Adjustments," in Fiscal Policy after the Financial Crisis, Alesina and Giavazzi eds., U. Chicago Press and NBER.

[3] Alesina, A., G. Cohen, and N. Roubini (1997), Political Cycles and the Macroeconomy, Cambridge, MA: MIT Press.

[4] Ames, B. (1987), Political Survival, Berkeley, CA: University of California Press.

[5] Banca d'Italia (2011). La ricchezza delle famiglie italiane 2010. Supplementi al Bollettino Statistico, Indicatori monetari e finanziari, Nuova serie, 64.

[6] Banfield, E. C. (1958).The Moral Basis of a Backward Society, Glencoe, IL: The Free Press.

[7] Ben-Porath, Y. (1975), "The Years of Plenty and the Years of Famine - A Political Business Cycle," Kyklos 28.

[8] Block, S., (2002). "Political business cycles, democratization, and economic reform: the case of Africa," Journal of Development Economics 67, 205 - 228.

[9] Bordignon, M. and G. Turati, (2014). "Electoral Rules and Municipal Finances: Evidence From Two Reforms in Italy," CESifo DICE Report, 24 - 28 (5). 
[10] Brender, A. and A. Drazen. (2005). "Political Budget Cycles in New Versus Established Democracies." Journal of Monetary Economics 52(7): 1271-1295.

[11] Brender, Adi and Allan Drazen (2008) "How Do Budget Decits and Economic Growth Affect Reelection Prospects? Evidence from a Large Panel of Countries", American Economic Review, 98(5): 2203-20.

[12] Drazen, A. and M. Eslava (2010) "Electoral Manipulation via Expenditure Composition: Theory and Evidence," Journal of Development Economics, 92, 39-52.

[13] Eslava M. (2006). "Ciclos Políticos de la Política Fiscal con Votantes Opuestos al Déficit: el Caso Colombiano." El Trimestre Económico 73(2): 289-.336

[14] Gonzàlez, M. (2002), "Do Changes in Democracy affect the Political Budget Cycle? Evidence from Mexico," Review of Development Economics 6, 204-224.

[15] Guiso, L., P. Sapienza and L. Zingales, (2013) "Long Term Persistence". Chicago GSB Research Paper No. 08-11.

[16] Keech, W. and K. Pak (1989), "Electoral Cycles and Budgetary Growth in Veterans' Benefit Programs," American Journal of Political Science 33, 901-11.

[17] Khemani, S. (2004), "Political Cycles in a Developing Economy: Effect of Elections in the Indian States. Journal of Development Economics 73, 125-154.

[18] Kneebone, R. and K. McKenzie (2001), "Electoral and Partisan Cycles in Fiscal Policy: An Examination of Canadian Provinces," International Tax and Public Finance 8, 753-774.

[19] Krueger, A. and I. Turan (1993), "The Politics and Economics of Turkish Policy Reform in the 1980's," in R. Bates and A. Krueger, eds. (1993), Political and Economic Interactions in Economic Policy Reform: Evidence from Eight Countries, Oxford: Basil Blackwell.

[20] Nannicini, T., A. Stella, G. Tabellini, and U. Troiano. 2013. "Social Capital and Political Accountability." American Economic Journal: Economic Policy, 5(2): 222-50.

[21] Neri, A. and M. T. Monteduro. (2013), "La ricchezza immobiliare delle famiglie italiane: un confronto fra dati campionari e censuari," Banca d'Italia, Questioni di Economia e Finanza (Occasional Papers).

[22] Persson, T. and G.Tabellini (2002), "Political Economics: Explaining Economic Policy", MIT Press. 
[23] Putnam, Robert D., Robert Leonardi and Rffaella Y. Nanetti Making Democracy Work . Princeton: Princeton University Press, 1993.

[24] Reid, B. G. (1998), Endogenous elections, electoral budget cycles and Canadian provincial governments Volume Public Choice 97 (1998), Issue 1-2, pp 35-48.

[25] Rogoff, K. (1990). "Equilibrium Political Budget Cycles." American Economic Review 80: 21-36.

[26] Rogoff, K. and A. Sibert (1988), "Elections and Macroeconomic Policy Cycles," The Review of Economic Studies, Vol. 55, No. 1, pp. 1-16.

[27] Schuknecht, L. (1996), "Political Business Cycles in Developing Countries," Kyklos 49, $155-70$.

[28] Shi, M. and J. Svensson (2006), "Political Budget Cycles: Do They Differ Across Countries and Why?," Journal of Public Economics 90 (2006) 1367 - 1389.

[29] Tufte, E. (1978), Political Control of the Economy, Princeton NJ: Princeton University Press. 


\section{Tables and Figures}

Table 1: Rates and Politics in 2012

\begin{tabular}{|c|c|c|c|}
\hline Panel A & rw & lw & Independent \\
\hline \hline Main Residence Av. & 4.21 & 4.29 & 4.20 \\
\hline Main Residence Av. Difference from Independent & 0.013 & 0.097 & 0 \\
\hline Additional Residence Av. & 8.67 & 8.89 & 8.33 \\
\hline Additional Residence Av. Difference from Independent & 0.33 & 0.56 & 0 \\
\hline Subsample Size & 892 & 789 & 5934 \\
\hline
\end{tabular}

\begin{tabular}{|c|c|c|c|c|}
\hline Panel B1: RIGHT-WING Munic. & Main Home $>$ Standard & Main Home $<$ Standard & Main Home=Standard & Total \\
\hline Additional Residence $>$ Standard & $25.1 \%$ & $6.4 \%$ & $31.8 \%$ & $63.3 \%$ \\
\hline Additional Residence $<$ Standard & $0 \%$ & $0.2 \%$ & $0.1 \%$ & $0.3 \%$ \\
\hline Additional Residence $=$ Standard & $2.5 \%$ & $1.8 \%$ & $32.1 \%$ & $36.3 \%$ \\
\hline Total & $27.6 \%$ & $8.4 \%$ & $64.0 \%$ & $100 \%$ \\
\hline
\end{tabular}

\begin{tabular}{|c|c|c|c|c|}
\hline Panel B2: LEFT-WING Munic. & Main Home $>$ Standard & Main Home $<$ Standard & Main Home $=$ Standard & Total \\
\hline Additional Residence $>$ Standard & $33.2 \%$ & $3.0 \%$ & $29.7 \%$ & $65.9 \%$ \\
\hline Additional Residence $<$ Standard & $0 \%$ & $1.4 \%$ & $1.3 \%$ & $2.7 \%$ \\
\hline Additional Residence=Standard & $1.6 \%$ & $2.0 \%$ & $27.8 \%$ & $31.4 \%$ \\
\hline Total & $34.9 \%$ & $6.5 \%$ & $58.7 \%$ & $100 \%$ \\
\hline
\end{tabular}

In Panel A we report average tax rates and difference from tax rates deliberated by independent municipalities.

In Panel B1 and B2 we report the joint frequencies in the deliberation of main (column) and additional (row) tax rates for right-wing and left-wing municipalities respectively. 
Table 2: Controls' Statistics

\begin{tabular}{|c|c|c|c|c|c|}
\hline Variable & Mean & St. Dev. & $\mathrm{N}$ & Min & Max \\
\hline \multicolumn{6}{|l|}{ Dependent Variables: } \\
\hline Main Residence first deliberation & 4.195 & 0.692 & 8092 & 2 & 6 \\
\hline Main Residence last deliberation & 4.206 & 0.709 & 8092 & 2 & 6 \\
\hline Additional Residence 2012 last deliberation & 8.683 & 1.294 & 8092 & 4.6 & 10.6 \\
\hline Additional Residence 2013 last deliberation & 8.686 & 1.124 & 8092 & 4.6 & 10.6 \\
\hline Additional Residence yearly change & 0.236 & 0.909 & 8092 & -4.6 & 4.6 \\
\hline \multicolumn{6}{|l|}{ Control Variables: } \\
\hline Population $^{a}$ & 7344.753 & 39741.76 & 8092 & 30 & 2617175 \\
\hline Territory size ${ }^{b}$ & 0.373 & 0.500 & 8089 & 0.002 & 13.077 \\
\hline Territory size^2 & 0.388 & 2.420 & 8089 & 0.000004 & 171.008 \\
\hline Altitude $^{c}$ & 0.358 & 0.298 & 8089 & 0 & 2.035 \\
\hline Altitude^2 & 0.216 & 0.338 & 8089 & 0 & 4.141 \\
\hline Education $^{d}$ & 0.259 & 0.061 & 8084 & 0.051 & 0.706 \\
\hline Active firms ${ }^{e}$ & 0.064 & 0.022 & 8088 & 0.007 & 0.307 \\
\hline Taxable income ${ }^{e}$ & 16189.29 & 3455.785 & 8092 & 6491.193 & 44270.7 \\
\hline Deficit $^{e}$ & -60.182 & 245.900 & 6222 & -4941.209 & 7466.184 \\
\hline Main Residences ${ }^{f}$ & 0.390 & 0.082 & 8086 & 0.123 & 1.053 \\
\hline Unemployment rate $(\%)^{a}$ & 0.102 & 0.063 & 8064 & 0.006 & 0.422 \\
\hline Right Wing Share & 0.117 & 0.322 & 7615 & 0 & 1 \\
\hline Left Wing Share & 0.104 & 0.305 & 7615 & 0 & 1 \\
\hline Margin of Majority ${ }^{g}$ & 25.246 & 26.193 & 7119 & -72.760 & 100 \\
\hline Non-profit Organisations ${ }^{e}$ & 5.399 & 11.862 & 7835 & 0 & 863.158 \\
\hline
\end{tabular}

a 2011 data

${ }^{b}$ hundreds of $\mathrm{km}^{2}$

$c$ thousands of $m$

$d$ share of graduated people on local population in 2001

e per capita

${ }^{f}$ per capita houses held by residents: it is a proxy of the number of people who hold their main habitation

${ }^{g}$ difference in share of votes in previous elections.

Tax rates are expressed as rate*10^3 
Table 3: Covariates Correlation with Treatment

\begin{tabular}{lcccc}
\hline Variables & Election 2013 & \multicolumn{3}{c}{ Election 2014 } \\
\hline \hline Population 2011 & 4,981 & $(1.155)$ & $-4,775^{* * *}$ & $(-4.844)$ \\
Area & 0.0133 & $(0.403)$ & $-0.0622^{* * *}$ & $(-4.435)$ \\
Area^2 & 0.179 & $(0.639)$ & $-0.137^{* *}$ & $(-2.192)$ \\
Altitude & -0.0115 & $(-1.217)$ & 0.00432 & $(0.598)$ \\
Altitude^2 & -0.00744 & $(-0.811)$ & -0.00802 & $(-0.892)$ \\
Share with University Degree & 0.00372 & $(1.518)$ & $-0.00611^{* * *}$ & $(-3.883)$ \\
Firms per capita & $0.00207^{* *}$ & $(2.425)$ & $-0.00279^{* * *}$ & $(-5.656)$ \\
Taxable Income Per Capita & $244.7^{* * *}$ & $(2.801)$ & $-206.6^{* * *}$ & $(-3.068)$ \\
Deficit Per Capita & 11.18 & $(1.479)$ & -6.037 & $(-0.840)$ \\
N. of Main Residences Per Capita & -0.00143 & $(-0.522)$ & -0.000153 & $(-0.0741)$ \\
Unemployment Rate 2011 & 0.000698 & $(0.420)$ & $-0.00295^{* * *}$ & $(-3.084)$ \\
Right Wing Government & $0.0378^{* *}$ & $(2.199)$ & $-0.0163^{*}$ & $(-1.696)$ \\
Left Wing Government & 0.000328 & $(0.0329)$ & $-0.0169^{*}$ & $(-1.927)$ \\
Margin of Majority in Previous Elections & -2.263 & $(-1.601)$ & $2.148^{* * *}$ & $(3.487)$ \\
Non-profit Organizations Per Capita & -0.117 & $(-0.538)$ & 0.331 & $(0.879)$ \\
\hline$<0.1 ;(* *) p<0.05 ;(* * *)$ & & & & \\
\hline
\end{tabular}

$(*) p<0.1 ;(* *) p<0.05 ;(* * *) p<0.01$.

Fixed-effects at the province level are included. T-statistics are reported in parenthesis. 
Table 4: The effects of elections on tax rate

\begin{tabular}{lcccccc}
\hline & $(1)$ & $(2)$ & $(3)$ & $(4)$ & $(5)$ & $(6)$ \\
\hline & Main & Main & Additional \\
Rate '12 & Rate '12 & $\begin{array}{c}\text { Additional } \\
\text { Rate '12 }\end{array}$ & $\begin{array}{c}\text { Additional } \\
\text { Rate '13 }\end{array}$ & $\begin{array}{c}\text { Additional } \\
\text { Rate '13 }\end{array}$ \\
\hline Election 2013 & & & & & & \\
& $-0.0840^{* *}$ & $-0.0870^{* * *}$ & -0.0498 & -0.0553 & & \\
Election 2014 & $(0.0328)$ & $(0.0331)$ & $(0.0517)$ & $(0.0577)$ & & $-0.233^{* * *}$ \\
& & & & & $-0.170^{* * *}$ \\
& & & & & $(0.0226)$ & $(0.0256)$ \\
\hline Controls & & $\mathrm{X}$ & & $\mathrm{X}$ & & $\mathrm{X}$ \\
\hline Observations & 8,091 & 6,199 & 8,091 & 6,199 & 8,091 & 6197 \\
Number of prov_cod & 110 & 108 & 110 & 108 & 110 & 108 \\
\hline
\end{tabular}

$(*) p<0.1 ;(* *) p<0.05 ;(* * *) p<0.01$.

Fixed-effects at the province level are included. Clustered standard errors at the province level are in parenthesis. Controls included are: population 2011, municipal area, municipal area squared, altitude, altitude squared, share of people with high school or University degree, number of firms per capita 2011, income per capita, deficit per capita, number of main habitations per capita, unemployment in 2011. The variables Election 2013 and Election 2014 equal 1 when the municipality has election in 2013 and 2014 respectively.

The dependent variable for columns (1) and (2) is the main residence rate set at the end of 2012, for columns (3) and (4) it is the additional residence rate at the end of 2012 and for columns (5) and (6) it is the additional residence rate at the end of 2013. 
Table 5: The effects of elections proximity on tax rates in 2012

\begin{tabular}{|c|c|c|c|c|}
\hline & $(1)$ & $(2)$ & (3) & (4) \\
\hline & Main & Main & Additional & Additional \\
\hline & Rate '12 & Rate '12 & Rate '12 & Rate '12 \\
\hline NTE & $\begin{array}{c}0.0335^{* * *} \\
(0.00851)\end{array}$ & $\begin{array}{c}0.0325^{* * *} \\
(0.0101)\end{array}$ & $\begin{array}{c}0.0941^{* * *} \\
(0.0167)\end{array}$ & $\begin{array}{c}0.0707^{* * *} \\
(0.0176)\end{array}$ \\
\hline Controls & & $\mathrm{X}$ & & $\mathrm{X}$ \\
\hline Observations & 6,835 & 5,306 & 6,835 & 5,306 \\
\hline Number of prov_cod & 110 & 108 & 110 & 108 \\
\hline
\end{tabular}

$(*) p<0.1 ;(* *) p<0.05 ;(* * *) p<0.01$.

Fixed-effects at the province level are included. Clustered standard errors at the province level are in parenthesis.

Controls included are: population 2011, municipal area, municipal area squared, altitude, altitude squared, share of people with high school or University degree, number of firms per capita 2011, income per capita, deficit per capita, number of main habitations per capita, unemployment in 2011. The variable NTE counts the number of years to the end of the term for each municipality.

The dependent variable for columns (1) and (2) is the main residence rate set at the end of 2012, while for column (3) and (4) it is the additional residence rate at the end of 2012 . 
Table 6: The effects of elections on the tax rates by geographical areas

\begin{tabular}{|c|c|c|c|c|c|c|}
\hline & $(1)$ & $(2)$ & $(3)$ & $(4)$ & $(5)$ & $(6)$ \\
\hline & North & North & Center & Center & South & South \\
\hline Panel A: & \multicolumn{6}{|c|}{ Main Rate 2012} \\
\hline Election 2013 & $\begin{array}{c}-0.0978^{* *} \\
(0.0361)\end{array}$ & $\begin{array}{l}-0.0691 \\
(0.0437)\end{array}$ & $\begin{array}{c}0.0629 \\
(0.0715)\end{array}$ & $\begin{array}{c}0.0505 \\
(0.0782)\end{array}$ & $\begin{array}{c}-0.113^{* *} \\
(0.0544)\end{array}$ & $\begin{array}{c}-0.147^{* *} \\
(0.0572)\end{array}$ \\
\hline Controls & & $\mathrm{X}$ & & $\mathrm{X}$ & & $\mathrm{X}$ \\
\hline Observations & 4,191 & 3,435 & 1,343 & 1,051 & 2,557 & 1,711 \\
\hline Number of Provinces & 38 & 36 & 31 & 31 & 41 & 41 \\
\hline Panel B: & \multicolumn{6}{|c|}{ Additional Rate 2012} \\
\hline Election 2013 & $\begin{array}{c}0.0750 \\
(0.0697)\end{array}$ & $\begin{array}{c}0.0526 \\
(0.0624)\end{array}$ & $\begin{array}{c}0.294^{* * *} \\
(0.0835)\end{array}$ & $\begin{array}{c}0.309^{* * *} \\
(0.0969)\end{array}$ & $\begin{array}{c}-0.224^{* * *} \\
(0.0684)\end{array}$ & $\begin{array}{c}-0.266^{* * *} \\
(0.0944)\end{array}$ \\
\hline Controls & & $\mathrm{X}$ & & $\mathrm{X}$ & & $\mathrm{X}$ \\
\hline Observations & 4,191 & 3,435 & 1,343 & 1,051 & 2,557 & 1,711 \\
\hline Number of Provinces & 38 & 36 & 31 & 31 & 41 & 41 \\
\hline Panel C: & \multicolumn{6}{|c|}{ Additional Rate 2013} \\
\hline Election 2014 & $\begin{array}{c}-0.252^{* * *} \\
(0.0280)\end{array}$ & $\begin{array}{c}-0.187^{* * *} \\
(0.0341)\end{array}$ & $\begin{array}{c}-0.274^{* * *} \\
(0.0493)\end{array}$ & $\begin{array}{r}-0.187^{* * *} \\
(0.0626)\end{array}$ & $\begin{array}{c}-0.170^{* * *} \\
(0.0558)\end{array}$ & $\begin{array}{c}-0.133^{* *} \\
(0.0566)\end{array}$ \\
\hline Controls & & $\mathrm{X}$ & & $\mathrm{X}$ & & $\mathrm{X}$ \\
\hline Observations & 4,191 & 3,435 & 1,343 & 1,051 & 2,557 & 1,711 \\
\hline Number of Provinces & 38 & 36 & 31 & 31 & 41 & 41 \\
\hline
\end{tabular}

$(*) p<0.1 ;(* *) p<0.05 ;(* * *) p<0.01$.

Fixed-effects at the province level are included. Clustered standard errors at the province level are in parenthesis. Controls included are: population 2011, municipal area, municipal area squared, altitude, altitude squared, share of people with high school or University degree, number of firms per capita 2011, income per capita, deficit per capita, number of main habitations per capita, unemployment in 2011. The variables Election 2013 and Election 2014 equal 1 when there are elections in 2013 and 2014 respectively.

The dependent variable is the main residence rate set at the end of 2012 in Panel A, the additional residence rate at the end of 2012 in Panel B and the additional residence rate at the end of 2013 in Panel C. 
Table 7: The effects of elections on the 2012 main residence rate by municipality population

\begin{tabular}{|c|c|c|c|c|c|c|}
\hline & $(1)$ & $(2)$ & $(3)$ & $(4)$ & $(5)$ & $(6)$ \\
\hline & Main & Main & Additional & Additional & Additional & Additional \\
\hline & Rate '12 & Rate '12 & Rate '12 & Rate '12 & Rate '13 & Rate '13 \\
\hline & $<15 \mathrm{~K}$ & $>15 \mathrm{~K}$ & $<15 \mathrm{~K}$ & $>15 \mathrm{~K}$ & $<15 \mathrm{~K}$ & $>15 \mathrm{~K}$ \\
\hline Election 2013 & $-0.109^{* * *}$ & 0.0413 & -0.0510 & -0.275 & & \\
\hline & & & & & & \\
\hline Election 2014 & & & & & $\begin{array}{c}-0.134^{* * *} \\
(0.0272)\end{array}$ & $\begin{array}{r}-0.0495 \\
(0.106)\end{array}$ \\
\hline Controls & $\mathrm{X}$ & $\mathrm{X}$ & $\mathrm{X}$ & $\mathrm{X}$ & $\mathrm{X}$ & $\mathrm{X}$ \\
\hline Observations & 5,642 & 555 & 5,642 & 555 & 5,642 & 555 \\
\hline
\end{tabular}

$(*) p<0.1 ;(* *) p<0.05 ;(* * *) p<0.01$.

Fixed-effects at the province level are included. Clustered standard errors at the province level are in parenthesis.

Controls included are: population 2011, municipal area, municipal area squared, altitude, altitude squared, share of people with high school or University degree, number of firms per capita 2011, income per capita, deficit per capita, number of main habitations per capita, unemployment in 2011. The variables Election 2013 and Election 2014 equal 1 when there are elections in 2013 and 2014 respectively.

The dependent variable is the main residence rate set at the end of 2012 in Columns 1 and 2, the additional residence rate at the end of 2012 in Columns 3 and 4 and the additional residence at the end of 2013 in Columns 5 and 6. 
Table 8: The effects of elections on tax rates: interaction with deficit

\begin{tabular}{|c|c|c|c|c|c|c|}
\hline & $(1)$ & $(2)$ & $(3)$ & (4) & $(5)$ & $(6)$ \\
\hline & $\begin{array}{c}\text { Main } \\
\text { Rate '12 }\end{array}$ & $\begin{array}{c}\text { Main } \\
\text { Rate '12 }\end{array}$ & $\begin{array}{c}\text { Additional } \\
\text { Rate '12 }\end{array}$ & $\begin{array}{c}\text { Additional } \\
\text { Rate '12 }\end{array}$ & $\begin{array}{c}\text { Additional } \\
\text { Rate '13 }\end{array}$ & $\begin{array}{c}\text { Additional } \\
\text { Rate '13 }\end{array}$ \\
\hline Deficit*Election2013 & $\begin{array}{c}0.000495^{* *} \\
(0.000230)\end{array}$ & $\begin{array}{c}0.000498^{* *} \\
(0.000234)\end{array}$ & $\begin{array}{c}0.000293 \\
(0.000361)\end{array}$ & $\begin{array}{c}0.000292 \\
(0.000340)\end{array}$ & & \\
\hline Election 2013 & $\begin{array}{c}-0.0697^{* *} \\
(0.0338)\end{array}$ & $\begin{array}{c}-0.0689 * * \\
(0.0335)\end{array}$ & $\begin{array}{l}-0.00477 \\
(0.0600)\end{array}$ & $\begin{array}{l}-0.0448 \\
(0.0570)\end{array}$ & & \\
\hline Deficit & $\begin{array}{c}0.0000637 \\
(0.0000441)\end{array}$ & $\begin{array}{c}0.0000627 \\
(0.0000429)\end{array}$ & $\begin{array}{l}0.000177^{* *} \\
(0.0000730)\end{array}$ & $\begin{array}{l}0.000176^{* *} \\
(0.0000688)\end{array}$ & $\begin{array}{c}0.000257^{* * *} \\
(0.0000955)\end{array}$ & $\begin{array}{r}0.000249^{* * *} \\
(0.0000785)\end{array}$ \\
\hline Deficit*Election2014 & & & & & $\begin{array}{r}-0.0000105 \\
(0.000131)\end{array}$ & $\begin{array}{l}0.0000009 \\
(0.000120)\end{array}$ \\
\hline Election2014 & & & & & $\begin{array}{c}-0.233^{* * *} \\
(0.0275)\end{array}$ & $\begin{array}{c}-0.170^{* * *} \\
(0.0261)\end{array}$ \\
\hline Controls & & $\mathrm{X}$ & & $\mathrm{X}$ & & $\mathrm{X}$ \\
\hline Observations & 6,222 & 6,199 & 6,222 & 6,199 & 6,222 & 6,199 \\
\hline R-squared & 0.003 & 0.015 & 0.003 & 0.076 & 0.016 & 0.085 \\
\hline Number of Provinces & 108 & 108 & 108 & 108 & 108 & 108 \\
\hline
\end{tabular}

$(*) p<0.1 ;(* *) p<0.05 ;(* * *) p<0.01$.

Fixed-effects at the province level are included. Clustered standard errors at the province level are in parenthesis. Controls included are: population 2011, municipal area, municipal area squared, altitude, altitude squared, share of people with high school or University degree, number of firms per capita 2011, income per capita, deficit per capita, number of main habitations per capita, unemployment in 2011. The variable Election 2013 and Election 2014 equal 1 when there are elections in 2013 and 2014 respectively. Deficit is the level of deficit per capital in 2011, while Deficit*Election2013 and Deficit*Election2014 are the interacted terms.

The dependent variable is the main residence rate set at the end of 2012 in column 1 and 2, the 2012 additional residence rate in column 3 and 4 and the 2013 additional residence rate in column 5 and 6 . 
Table 9: The effects of elections on tax rates in 2012: interaction with deficit in big and small municipalities

\begin{tabular}{|c|c|c|c|c|c|c|c|c|}
\hline & (1) & (2) & (3) & (4) & (5) & (6) & (7) & (8) \\
\hline & \multicolumn{4}{|c|}{ Main Rate 2012} & \multicolumn{4}{|c|}{ Additional Rate 2012} \\
\hline & $<5 \mathrm{~K}$ & $<5 \mathrm{~K}$ & $>5 \mathrm{~K}$ & $>5 \mathrm{~K}$ & $<5 \mathrm{~K}$ & $<5 \mathrm{~K}$ & $>5 \mathrm{~K}$ & $>5 \mathrm{~K}$ \\
\hline \multirow[t]{2}{*}{ Deficit*Elec2013 } & $0.000598^{* *}$ & $0.000602^{* *}$ & -0.000178 & -0.000094 & $0.000680^{*}$ & 0.000598 & -0.000427 & -0.000441 \\
\hline & $(0.000255)$ & $(0.000258)$ & $(0.000400)$ & $(0.000391)$ & $(0.000367)$ & $(0.000369)$ & $(0.000720)$ & $(0.000708)$ \\
\hline \multirow[t]{2}{*}{ Election 2013} & $-0.130 * * *$ & $-0.122^{* * *}$ & -0.0330 & -0.0283 & -0.0243 & -0.0295 & -0.134 & -0.151 \\
\hline & $(0.0424)$ & $(0.0414)$ & $(0.0511)$ & $(0.0506)$ & $(0.0627)$ & $(0.0601)$ & $(0.100)$ & $(0.0993)$ \\
\hline \multirow[t]{2}{*}{ Deficit } & 0.000038 & 0.000039 & $0.000385^{* *}$ & 0.000262 & $0.000171^{* *}$ & $0.000163^{* *}$ & 0.000232 & 0.000425 \\
\hline & $(0.000043)$ & $(0.000042)$ & $(0.000152)$ & $(0.000163)$ & $(0.000072)$ & $(0.000065)$ & $(0.000312)$ & $(0.000320)$ \\
\hline Controls & & $\mathrm{X}$ & & $\mathrm{X}$ & & $\mathrm{X}$ & & $\mathrm{X}$ \\
\hline Observations & 4,351 & 4,328 & 1,871 & 1,869 & 4,351 & 4,328 & 1,871 & 1,869 \\
\hline Number of Provinces & 106 & 106 & 107 & 107 & 106 & 106 & 107 & 107 \\
\hline
\end{tabular}

$(*) p<0.1 ;(* *) p<0.05 ;(* * *) p<0.01$.

Fixed-effects at the province level are included. Clustered standard errors at the province level are in parenthesis.

Controls included are: population 2011, municipal area, municipal area squared, altitude, altitude squared, share of people with high school or University degree, number of firms per capita 2011, income per capita, deficit per capita, number of main habitations per capita, unemployment in 2011. The variable Election 2013 equals 1 when there are elections in 2013. Deficit is the level of deficit per capital in 2011, while Deficit*Election2013 is the interacted term.

The dependent variable is the main residence rate set at the end of 2012 in columns 1 to 4 and the additional residence tax rate in 2012 in columns 5 to 8 . In column 1,2, 5 and 6 we report results for municipalities with less than 5000 inhabitants, while in $3,4,7$ and 8 there are municipalities with more than 5000. 
Figure 1: Timeline of the Reform

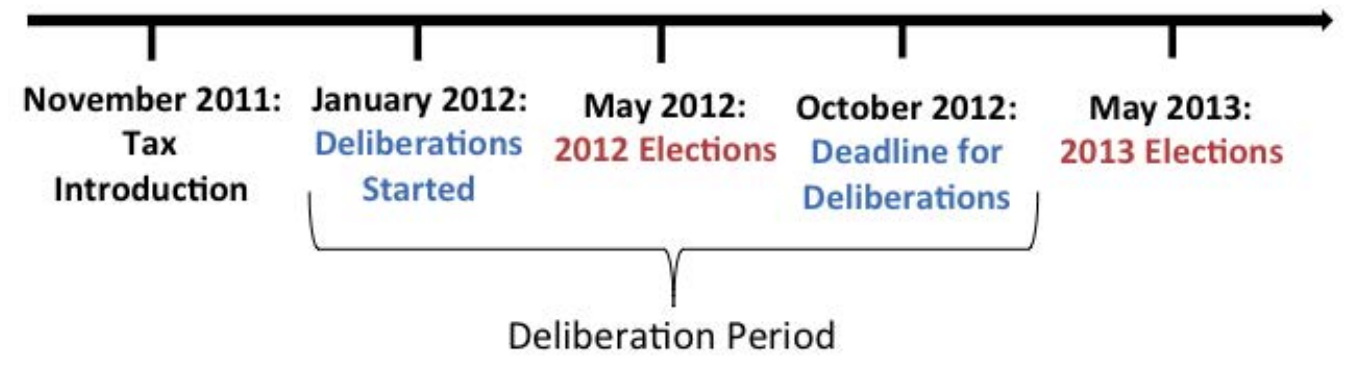


Figure 2: Permutation Test
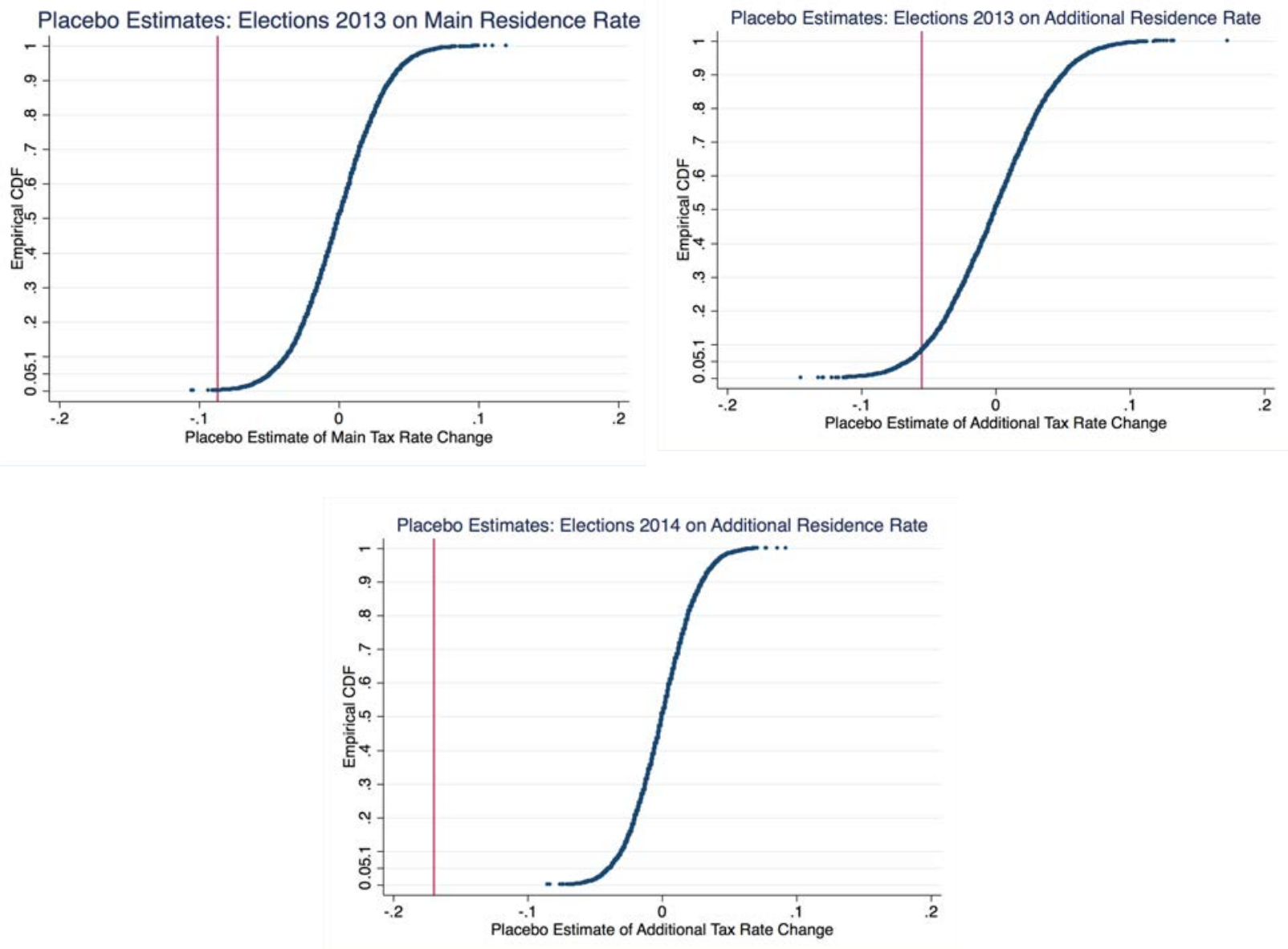